\title{
INFLUENCE OF SHORT-TERM FASTING ON THE CHANGES IN WOMEN'S CARDIOVASCULAR FUNCTIONAL PARAMETERS
}

\author{
Sandra Bardauskienè $\dot{1}^{1}$ Algè Daunoravičiene் $\dot{e}^{1}$, Alfonsas Vainoras ${ }^{1}$, Aurelija Venskaitytè $^{1,2}$, \\ Inga Muntianaitė Dulkiniené ${ }^{1}$ \\ Lithuanian University of Health Sciences ${ }^{l}$, Kaunas, Lithuania \\ Lithuanian Academy of Physical Education ${ }^{2}$, Kaunas, Lithuania
}

\begin{abstract}
Research background and hypothesis. Recently, cardiovascular diseases (CVD) have been the major cause of mortality as a result of poor diet, emotional stress and insufficient physical activity. Improvement of dietary habits based on reduction of body weight by short-term or long-term fasting has been observed. While analyzing the effect of fasting, its psychological rather than physiological features are usually emphasized.

Research aim was to assess the impact of daily fasting on the changes in women's cardiovascular functional parameters during physical load.

Research methods. Thirty six women performed exercise test on bicycle ergometer (the load increased each minute by $25 \mathrm{~W}$ ) before and after 24 hours of fasting. After the $1^{\text {st }}$ exercise test the subjects used only non-energetic liquid. Evaluation of electrocardiogram (ECG) data was performed applying computerized ECG analysis system "Kaunas-Load"(Institute of Cardiology, LUHS). We analyzed systolic blood pressure (S), heart rate (HR) and JT interval at rest and throughout the load.

Research results. After 24 hours of fasting, HR of women at rest and during the first 3 minutes of the load significantly decreased $(\mathrm{p}<0.05)$. Duration of the JT interval decreased during both exercise tests. Longer JT interval was obtained at rest and during the first 2 minutes of the load after 24 hours of fasting $(\mathrm{p}<0.05)$. S at rest and throughout the load was significantly lower after fasting $(\mathrm{p}<0.05)$.

Discusion and conclusions. Functional state evaluation of untrained women after 24 hours of fasting during bicycle ergometery test demonstrated dynamical changes of many cardiovascular function variables: lower HR, increased the JT interval, and decreased S.
\end{abstract}

Keywords: cardiovascular system, short-term fasting, bicycle ergometer test.

\section{INTRODUCTION}

$\mathrm{E}$ motional stress, fatigue, sleep disorders and improper diet are basic factors resulting in ischemic heart disease, angina pectoris, myocardial infarction or stroke (Singh et al., 2001). In order to maintain the body functions, first of all, whatever their reasons (health problems, religion, etc.), people change their dietary habits (Johnson, Leck, 2010). Even 14\% of Americans were fasting for weight reduction or weight control, which contributed to the solution of the obesity problem. However, other medical documents witnessed the data of the consequences of long-term fasting, in particular, those with normal body weight (participants of hunger strike, prisoners of war, victims of famine, etc.) (Johnstone, 2003). 
Fasting is defined as a period of having low intake or abstinence from all vital nutrients. During this period, first of all, the changes related to the cardiovascular system (CVS), frequently defined as pathological, occur (Singh et al., 2001; Zhang et al., 2010). Following the meal, during the period of 3-12 hours the body undergoes an "early“ fasting phase, which is called post-absorbtive. After this phase, a „real“ fasting phase marked by hypoglycemia and increased glucogenic activity occurs (Varady, Hellerstein, 2007).

Excess of energetic substances also trigger negative consequences, since they accumulate in the body as fats resulting in cardiovascular diseases (CVD) or diseases of other funtional systems (Vaisvalavičius et al., 2006).

Homeostasis is maintaned not only by wellbalanced diet but also by physical activity two inseparable factors. Improper diet places an additional stress on the body and may limit daily possibilities of physical activity (Vizbaraite, Petronyte, 2005; Johnson, Leck, 2010). Short-term fasting affects the general body function. Studies demonstrated that due to fasting, sportspeople's aerobic endurance reduces and reaction time increases, and heart rate (HR) as well as lactate level increase during load (Ainslie et al., 2003; Johnson, Leck, 2010).

Our literature review showed that most common fasting was observed when investigating elite athletes. Moreover, the changes of cognitive functions are analysed rather than alterations of the parameters of functional systems (Rampersaud et al., 2005; Johnson, Leck, 2010). There is still a lack of evidence that fasting affects functional capacity of non-sporting individuals. Therefore, it is hypothesized that short-term fasting (24 hours), when an individual has no intake of nutrients and consumes only water, affects the parameters of the cardiovascular system (CVS). When analysing CVS, our studies allow more comprehensive evaluatation of adaptation of the human body to physical loads and changes following twenty four hours. Interpretations of the data based on the model of intergrated evaluation of human organism as a complex adaptive system proposed by A. Vainoras is widely used in analogous interpretations in Lithuania as well as beyond it (Vainoras et al., 2008).

The aim of the study was to assess the impact of daily fasting on the changes in the cardiovascular functional parameters of women during physical load.

\section{RESEARCH METHODS}

The study included 36 women who did not have any health complaints and whose ECG were without any pathological changes. The mean age of participants was $32.03 \pm 1.57$ years, height $170 \pm 0.14 \mathrm{~cm}$, weight $-71.96 \pm 2.56 \mathrm{~kg}$, BMI $24.71 \pm 0.69 \mathrm{~kg} / \mathrm{m}^{2}$.

The participants performed an increasing every 1 minute (by $25 \mathrm{~W}$ ) exercise test on a bicycle ergometer before and after 24 hours of fasting. After the first bicycle ergometry test the subjects only used liquid of no energizing value (water). In order to evaluate the functional state of the cardiovascular system we used a computerized electrocardiogram (ECG) analysis system „Kaunas-load“, which was developed at the Institute of Cardiology, LUHS. Both tests were performed from 6 to 8 o'clock in the evening. Synchronously 12 leads of ECG and the arterial blood pressure were recorded during the bicycle ergometry test. The initial load of bicycle ergometry for all participants was $25 \mathrm{~W}$, every minute increased by $25 \mathrm{~W}$ up to $150 \mathrm{~W}$. The workload level was evaluated as higher than average, but not maximum. The speed of workload was 60-65 rpm. Every minute arterial blood pressure was measured before the load and during the workload. During the investigations systolic blood pressure (S), heart rate (HR) and JT interval dynamics were estimated.

Student $t$ test was used for paired samples to evaluate the confidence level of the data. The differences were valued as statistically significant, if $p<0.05$. The results are presented as arithmetic mean \pm standard deviation.

\section{RESEARCH RESULTS}

When evaluating the changes of regulatory processes of HR, HR changes were analysed. Based on the results of the study, prior to fasting, the relative resting HR of the investigated women was $87.38 \pm 2.23$ beats / min. During the exercise test HR increased with an increase of workload (by $25 \mathrm{~W}$ ) and after the development of maximal power $(150 \mathrm{~W})$ it reached $145.82 \pm$ 2.73 beats / min. Repeated exercise test after 24 hours of fasting revealed a significantly decreased HR of $81.83 \pm 2.20$ beats / min at a relatively steady state $(p<0,05)$. The comparison of the data of cycling exercise performed at different levels of intensity showed that statistically significant 

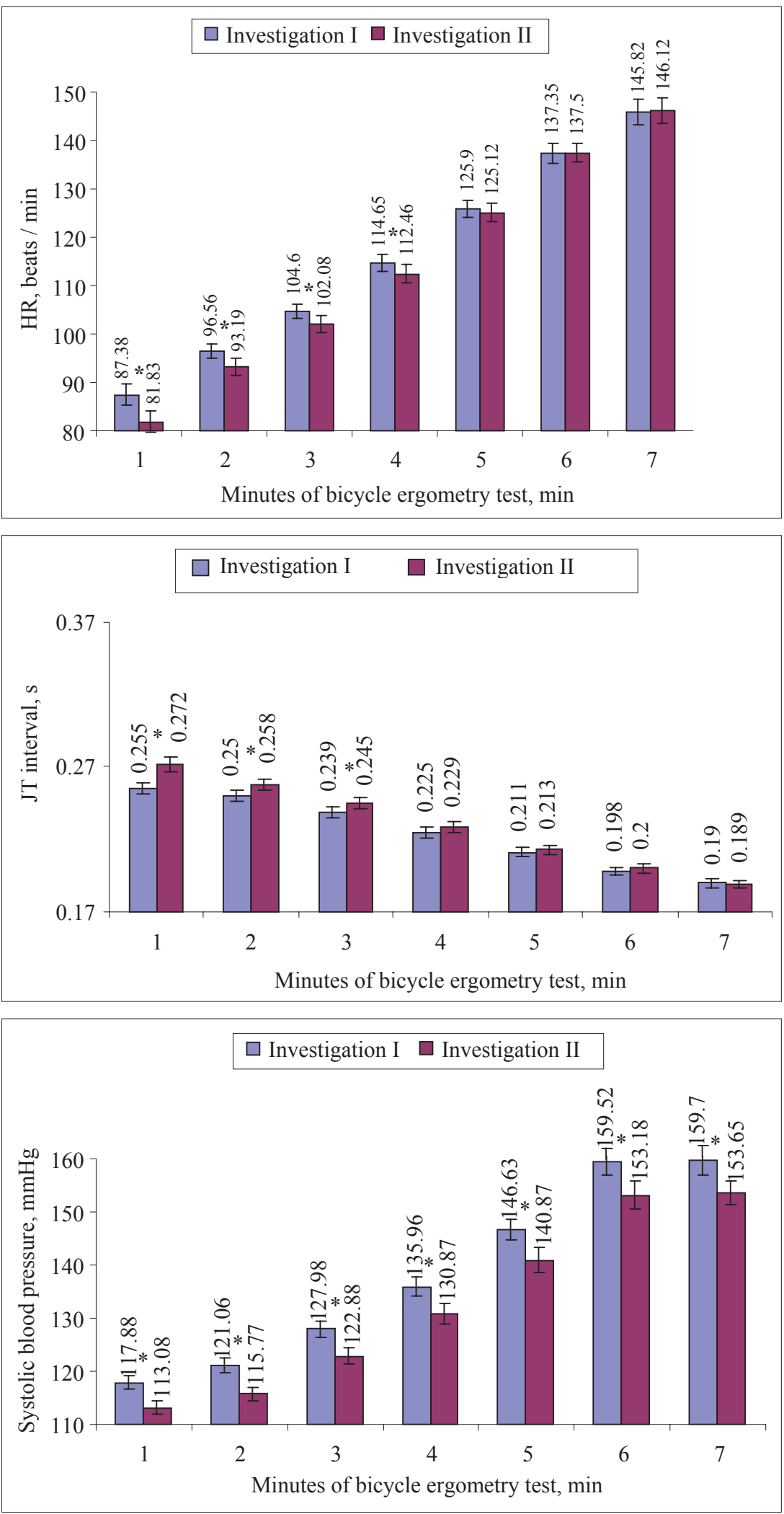

Figure 1. HR changes during investigation I and II

Note. $*-p<0.05$

Figure 2. JT interval changes during investigation I and II

Note. ${ }^{*}-\mathrm{p}<0.05$.

Figure 3. Systolic blood pressure changes during investigation I and II

Note. ${ }^{*}-\mathrm{p}<0.05$ heart rate variability was recorded at the second $(25 \mathrm{~W})$, third $(50 \mathrm{~W})$ and fourth $(75 \mathrm{~W})$ minutes $(\mathrm{p}<0.05)$, while at the fifth $(100 \mathrm{~W})$, sixth $(125 \mathrm{~W})$ and seventh minutes $(150 \mathrm{~W})$ there was a slight difference in the results $(p>0.05)$. After fasting, the maximal recorded HR during exercise test was $146.12 \pm 2.58$ beats / min (Figure 1).
Analysis of the JT interval, which reflects metabolism changes, demonstrated the shortening of this interval during the cycling exercise test. This apparent trend was observed both during the first test and the repeated test following 24-hour-fasting (Figure 2). However, HR (see Figure 1) and JT interval (see Figure 2) 
differences at higher power before and after fasting disappeared.

The comparison of the results of both tests determined that JT duration over the first test $(0.255 \pm 0.004 \mathrm{~s})$ statistically significantly differed from JT interval that was recorded after fasting $0.272 \pm 0.005 \mathrm{~s}(\mathrm{p}<0.05)$. At the second and third minutes (power corresponds to $25 \mathrm{~W}$ and $50 \mathrm{~W}$ ) the values of the JT interval significantly differed prior to and after fasting $(\mathrm{p}<0.05)$. The shortening of the JT interval during the workload ranged from minimal $(25 \mathrm{~W})$ to maximal $(150 \mathrm{~W})$ level of intensity, however, the tendencies of longer values of the JT interval were recorded following 24-hour fasting.

Evaluation of systolic ABP data that were received during bicycle ergometer prior to fasting and following 24-hour-fasting revealed that the diferences were statistically significant during all work load ( $\mathrm{p}<0.05)$. Before the first investigation the resting systolic blood pressure was $117.88 \pm$ $1.17 \mathrm{mmHg}$, and after 24-hours of fasting it was $113.08 \pm 1.25 \mathrm{mmHg}(\mathrm{p}<0.05)$.

Systolic blood pressure increased with an increase in levels of intensity from $25 \mathrm{~W}$ to $150 \mathrm{~W}$ and reached the maximal value of $159.70 \pm$ $2.68 \mathrm{mmHg}$ before fasting, but after fasting systolic blood pressure of $153.65 \pm 2.28 \mathrm{mmHg}$ was determined $(\mathrm{p}<0.05)$ (Figure 3$)$.

\section{DISCUSSION}

Recently, more attention has been focused on the risk factors that are associated with CVS, which account for the highest rate of mortality (Folta, Nelson, 2010). Therefore, awareness of physical activity and dietary habits that are based on recommendations of cardiologists, are promoted. In order to maintain the optimal or proper body function, an increase of level of physical capacity as well as adaptation to diet in terms of its quality, quantity and frequency are taking place (Singh et al., 2001; Folta, Nelson, 2010). Thus changes in body mass that are linked to health disorders (diabetes, hypertension, dyslipidemia, obesity, etc.) can be controlled (Zhang et al., 2010). Not rarely, short-term or long-term fasting is used to reduce body weight whatever its reasons might be: disease or esthetics. However, the studies that analyse the impact of fasting are more concerned with changes in cognitive processes rather than funcional body systems, i. e., more attention is drawn to psychological rather than physiological processes (Rampersaud et al., 2005).
Apparently body weight changes have influence on the activity of the cardiovascular system, thus it is important to analyze adaptation of CVS under changing conditions. HR, which reflects the peculiarities of mobilization function of CVS during exercises, is the most commonly analysed parameter in scientific studies, since its variability is observed from the first seconds of load (Shephard, Balady, 1999). In addition, it is particularly easily and reliably recorded. HR increases with the gradual increase of workload. The increase of HR during load results from alteration of the sympathic nervous system activity.

Obviously, proportional increase of HR values observed during exercise test were also evident after the day of fasting. Lower HR values at rest and onset of workload showed early CVS response to 24-hour fasting, which may be conditioned upon the tone of the parasympathetic system increases and energetic substrates reduction in blood. Our obtained results confirmed R. B. Singh's et al. (2001) proposition that fasting is also a decisive factor of the resting and the exercising HR variability.

According to the model of intergrated evaluation of human organism as a complex adaptive system it is known that in the evaluation of the human body during workload not only HR shows the state of it. JT interval illustrates the course of ventricular repolarization process, and may be used as a parameter of repolarization duration (Perkiomaki, 2003). Change of JT intervals over work load is linked to variability of myocardium metabolism and correlates (there is a strong and very strong negative correlation) with HR increase (Jarusevičius, 2000). When JT interval shortens to $160 \mathrm{~ms}$, the maximal rate of metabolism in the heart is reached (Poderys et al., 2007). When performing every minute increasing cycling exercise test prior to fasting (investigation I), and after 24-hour-fasting (investigation II) JT interval values recorded after maximal power $(150 \mathrm{~W})$ did not shorten to the minimal duration (160 ms) (Hlaing et al., 2005). A comparison of the results of both studies revealed that significant changes in the heart metabolism were determined at rest and during the first two levels of intensity $(25$ and $50 \mathrm{~W})(p<0.05)$. Thus, duration of ventricular repolarization following 24 hours of fasting significantly increased, and the rates of heart metabolism were slower at lower workloads and this process disappeared at more intensive 
workloads, what goes well with the changes in the specificity of the HR dynamics. 24-hour fasting did not lead to myocardial metabolic pathological deviations.

The circulation system adapts to the body needs and provides blood supply to all organs; with blood the body obtains oxygen and nutrients. Thus, when the body adapts to the environmental conditions and increasing intensity of physical activity, regulatory system of the body, which similarly determines alterations of $\mathrm{HR}$, redistributes blood flow in the body. ABP dynamics demonstrates changes occurring in blood vessels, redistributing hemodynamical flows (Evrengul, 2006). Variation in hemodynamics, including an increasing HR and systolic blood pressure shows that regulatory system of the body analogously influences these two indexes, but observed differences between last-mentioned indexes reveals undefined fact that specifics of their management is different. Thus, only an increased parasympathetic tone after fasting could not explain this phenomenon
According to the other studies (Singh et al., 2001), our results also confirmed the statement that even 24-hour fasting also determines significantly decreased systolic ABP, both at rest and during exercise test (bicycle ergometry test). The findings of our study support this claim as recorded values of systolic ABP during all levels of intensity were significantly smaller after fasting $(p<0.05)$. Differently from evaluation of HR or JT interval, values of systolic ABP during maximal load $(150 \mathrm{~W})$ were also significantly smaller after fasting $(\mathrm{p}<0.05)$.

\section{CONCLUSIONS AND PERSPECTIVES}

The analysis of the assessment of the functional state of untrained women after 24 hours of fasting while they were performing a bicycle ergometry test demonstrated the change of dynamics of many variables of the cardiovascular function: A lower heart rate, an increase in the JT interval duration, and a decrease of systolic blood pressure.

\section{REFERENCES}

Ainslie, P., Campbell, I., Frayn, K. et al. (2003). Physiological metabolic and performance implications of a prolonged hill walk: Influence of energy intake. Journal of Applied Physiology, 94, 1075-1083.

Evrengul, H., Tanriverdi, H., Kose, S. et al. (2006) The realationship between heart rate recovery and heart rate variability in coronary artery disease. Annals of Noninvasive Electrocardiology, 11 (2),154-162.

Folta, S. C., Nelson, M. E. (2010). Reducing cardiovascular disease risk in sedentary, overweight women: Strategies for the cardiovascular specialist. Current Opinion in Cardiology, 25 (5), 497-501.

Hlaing, T., Dimino, T., Kowey P. R., Yan, G. X. (2005). ECG Repolarization Waves: Their Genesis and Clinical Implications Annals of Noninvasive Electrocardiology, 10 (2), 211-223.

Jarusevičius, G. (2000). Išeminès širdies ligos požymiu fizinio krūvio metu paieška ir j̇vertinimas pagal vainikiniu arteriju pažeidimo vieta: daktaro disertacija. Kaunas: KMU.

Johnson, S., Leck, K. (2010). The effects of dietary fasting on physical balance among healthy young women. Nutrition Journal, 13, 9-18.

Johnstone, A. M. (2003). Fasting - the ultimate diet? European Journal of Clinical Nutrition, 57 (2), 30-38.

Perkiomaki, S. J. (2003). Nonlinear dynamics of heart rate and repolarization. International Journal of Bioelectromagnetism, 5 (1), 300

Poderys, J., Vainoras, A., Korsakas, S. et al. (2007). ECG and motion activity monitoring during the walking and running tasks. Sporto mokslas, 3 (49), 48-52.
Rampersaud, G. C., Pereira, M. A., Girard, B. L., Adams, J., Metzl, J. D. (2005). Breakfast habits, nutritional status, body weight, and academic performance in children and adolescents. American Dietetic Association, 105 (5), 743-760.

Shephard, R. J., Balady, G. J. (1999). Exercise as cardiovascular therapy. Circulation, 99, 963-972.

Singh, R. B., Weydahl, A., Otsuka, K. et al. (2001). Can nutrition influence circadian rhythm and heart rate variability? Biomedicine and Pharmacotherapy, 55 (1), 115-124.

Vainoras, A., Daunoravičienė, A., Šiupšinskas, L. et al. (2008). Kineziologija: mokomoji knyga. Kaunas: Vitae Litera.

Vaisvalavičius, V., Petkevičienė, J., Klumbienė, J. (2006). Lietuvos moterų požiūris ì savo kūno svorị ir nutukimo dažnumas. Lietuvos akušerija ir ginekologija, 9 (2), 9296.

Varady, K. A., Hellerstein, M. K. (2007). Alternate-day fasting and chronic disease prevention: a review of human and animal trials. American Journal of Clinical Nutrition, 86 (1), 7-13.

Vizbaraitè, D., Petronytė, G. (2005). 14-18 metų mokinių mitybos ir fizinio aktyvumo sasaja. Visuomenès sveikata, 3 (30), 41-45.

Zhang, L., Qin, L. Q., Liu, A. P., Wang, P. Y. (2010). Prevalence of risk factors for cardiovascular disease and their associations with diet and physical activity in suburban Beijing, China. Journal of Epidemiology, 20 (3), 237-243. 


\title{
TRUMPALAIKIO BADAVIMO İTAKA MOTERŲ ŠKS FUNKCINIŲ RODIKLIU KAITAI
}

\author{
Sandra Bardauskiene் $\dot{1}^{1}$ Algė Daunoravičiene் ${ }^{1}$, Alfonsas Vainoras ${ }^{1}$, Aurelija Venskaitytė ${ }^{1,2}$, \\ Inga Muntianaitė Dulkiniené ${ }^{1}$ \\ Lietuvos sveikatos moksly universitetas ${ }^{1}$, Kaunas, Lietuva \\ Lietuvos kūno kultūros akademija², Kaunas, Lietuva
}

\section{SANTRAUKA}

Tyrimo pagrindimas ir hipotezė. Pastaruoju metu širdies ir kraujagyslių sistemos (ŠKS) ligos yra pagrindinè mirštamumo priežastis, kurią lemia netinkama mityba, stresas, fizinio aktyvumo sumažejimas. Siekiant teigiamu pokyčių, neretai mažinamas kūno svoris trumpalaikiu arba ilgalaikiu badavimu. Visgi tiriant badavimo poveiki dažniau akcentuojami psichologiniai, o ne fiziologiniai veiksniai.

Tikslas: i̇vertinti paros badavimo poveiki moterų ŠKS funkcinių rodiklių kaitai fizinio krūvio metu.

Metodai. 36 moterys atliko pakopomis (po $25 \mathrm{~W}$ ) kas 1 minutę didinamo fizinio krūvio veloergometrini mègini prieš badavimą ir praejjus 24 valandoms po jo. Tiriamosios po pirmo veloergometrinio mèginio 24 valandas vartojo tik vandeni. ŠKS funkcinei būklei vertinti buvo naudojama KMU Kardiologijos institute sukurta kompiuterizuota EKG analizės sistema „Kaunas-Krūvis“. Tyrimo metu buvo analizuota sistolinio kraujospūdžio (S), širdies susitraukimų dažnio (ŠSD) ir JT intervalo kaita ramybès sąlygomis, fizinio krūvio metu.

Rezultatai. Po 24 valandų badavimo ŠSD ramybės sąlygomis ir pirmas tris krūvio minutes reikšmingai sumažèjo $(\mathrm{p}<0,05)$. JT intervalo trukmè viso fizinio krūvio metu trumpėjo. Užregistruotos ilgesnès JT intervalo reikšmès ramybès metu ir pirmas dvi fizinio krūvio minutes po badavimo $(\mathrm{p}<0,05)$. S ramybės sąlygomis ir viso fizinio krūvio metu po paros badavimo reikšmingai sumažèjo $(\mathrm{p}<0,05)$.

Aptarimas ir išvados. Vertinant nesportuojančių moterų funkcinę būklę po paros badavimo, daugelis ŠKS funkcinių rodiklių buvo pakitę: užregistruotas mažesnis ŠSD, pailgèjęs JT intervalas ir sumažėjęs S.

Raktažodžiai: širdies ir kraujagyslių sistema, trumpalaikis badavimas, veloergometrinis mėginys.

Gauta 2010 m. spalio $26 \mathrm{~d}$.

Received on October 26, 2010

Priimta $2011 \mathrm{~m}$. kovo $17 \mathrm{~d}$.

Accepted on March 17, 2011

Corresponding author Sandra Bardauskienè

Lithuanian University of Health Sciences

A. Mickevičius str. 9, LT-44307 Kaunas

Lithuania

$\mathrm{Tel}+370730580$

E-mail bardauskiene@gmail.com 